\title{
REKONSTRUKSI PARADIGMA PENDIDIKAN AGAMA ISLAM ERA GLOBALISASI
}

\section{Oleh \\ Lazuardi Harahap}

\begin{abstract}
Gobalization not only enriches the innovative echievements of science and technology, especially, in the aspect of information, telecomunication, and transportation, but also impacts to stimulate degradation of the humanities values and style life of peoples. In one side, globalization endorses liberation and multiinteraction among the peoples, and in other side, it also tends to stimulate fanatism, exclusivism, radicalism, chauvism, and anarchism in the name of tribalism, rascism, religion, sects, and ect. In the context of globalization era, it is important to reconstruct the "old fashion" of classical religious Islamic education with the humanictic-multicultural paradigm. It has to make its priority in powering how to widespread the universal values of humanity, how to make solidarity in plural societies, how to live together peaceful and harmony with mutual understanding and cooperation among the peoples individually and socially. Therefore, curriculum, matters, metholodologies, tools, sytems of evaluation, and culture of religious Islamic education have to be reformulated.
\end{abstract}

\section{Key words: Globalization, Islamic education, Humanistic- Multicultural, Reconstruction}

\section{A. Pendahuluan}

Globalisasi telah melahirkan bermacam paradoks dalam kehidupan umat manusia. Kemajuan di bidang ilmu pengetahuan dan teknologi telah meningkatkan kemampuan manusia mengakses informasi dan mempersingkat jarak transportasi sehingga batas-batas wilayah, budaya, dan agama menjadi sulit dipertahankan. Interaksi dan pergaulan umat manusia nyaris tanpa sekat, sehingga mempercepat daya jangkau pengaruh budaya asing dan gaya hidup tertentu dari luar negeri. Namun, sekalipun fenomena modernitas dan globalisasi ini telah 
menjadikan dunia sebagai desa buana (global village) dengan kesadaran akan eksistensi "orang lain" (the others/out siders) di luar diri atau kelompok sendiri (in siders), pada kenyataannya penguatan identitas sosial, budaya, dan agama semakin mencuat. Bahkan, dalam kehidupan kemasyarakatan dan keagamaan dewasa ini semakin sering muncul pertentangan dan perbenturan kultural, sosial, etnis, dan agama yang melibatkan masyarakat sipil (seperti terjadi di Aceh, Maluku, dan Poso), dan militer (seperti terjadi di Israel, Chechnya, Kashmir, Irlandia, dan Irak). Dalam pada itu, sekalipun manusia di zaman ini dipandang relatif mampu meningkatkan taraf ekonomi, namun pencapaian itu telah menggiring manusia modern bersikap dan berperilaku konsumeristik, kapitalistik, materialistik, dan hedonistik disertai kegelisahan psikologis dan teologis, insekuritas (ketidakamanan), ketidaktenangan, ketidakadilan secara individual maupun sosial.

Fenomena kehidupan sosial-keagamaan era globalisasi dengan segala dampaknya itu, secara positif maupun negatif, pada gilirannya menawarkan peluang dan sekaligus tantangan baru bagi dunia pendidikan, khususnya di bidang pendidikan Islam. Pertanyaan yang muncul kemudian adalah telah cukup siapkah pendidikan Islam, dalam pengertian yang seluas-luasnya, merespons dan mengantisipasi perubahan dan perkembangan interaksi sosial era kekinian itu. Pertanyaan ini penting untuk dikedepankan mengingat literatur dan materi pendidikan Islam, baik di tingkat sekolah dasar, sekolah menengah, dan perguruan tinggi, hampir semua masih berbicara "era klasik", skolastik, pramodern, dan belum banyak bersentuhan dengan era globalisasi. Kalau pun terdapat uraian tentang modernisasi dan globalisasi, respons terhadapnya lebih banyak bersifat apologetik dan penghakiman (value judgment) daripada bersifat informatif. 
Sementara peta wilayah modernisasi dan globalisasi kurang begitu mendapat perhatian dan pengkajian secara serius dan mendalam dalam pendidikan Islam. ${ }^{1}$

Guna menjawab persoalan di bidang pendidikan Islam dewasa ini, diperlukan keberanian intelektual untuk melakukan konsesi-konsesi tertentu secara menyeluruh menyangkut perubahan kurikulum, materi, metodologi, dan institusi pendidikan, sehingga diharapkan dapat menghantarkan anak didik agar tidak mudah terkontaminasi oleh budaya modernitas dengan cara yang fleksibel dan tidak kaku. Peserta didik perlu memahami struktur fundamental dari kehidupan modern agar mereka dapat mengamalkan ajaran-ajaran Islam dengan tenang tanpa dibayang-bayangi oleh ketakutan, kecemasan, kegusaran, kegelisahan, dan perasaan bersalah. Peserta didik dapat memaknai dan menghadapi modernitas dengan penuh kearifan. Mereka tidak terlampau berani meleburkan diri ke dalam budaya modern yang dapat menggiring kepada sikap relativistik-nihilistik dan mereka tidak pula terlampau takut menghadapinya sehingga memunculkan sikap fundamentalis-eksklusif. Mereka dapat dengan cerdas memanfaatkan nilai-nilai dan kemajuan modernitas, khususnya di bidang ilmu pengetahuan, teknologi, dan informasi, guna mempermudah dan meningkatkan kuantitas pengaplikasian nilai-nilai moral spiritual keagamaan dalam kehidupan sehari-hari di seluruh bidang. Dalam pada itu, perlu diciptakan berbagai upaya yang dapat menambah, mengembangkan, dan memperkaya intensitas saling tukar menukar pengetahuan yang dapat dipercaya tentang berbagai agama (aspek doktrin) dan kehidupan sosial keagamaan (aspek

1 M. Amin Abdullah, "Pendidikan Islam dan Tantangan Modernitas," dalam Pendidikan Agama Era Multikultural Multireligius, (Jakarta: PSAP, 2005), h. 70-72. 
empiris-historis) dengan menghindarkan sikap menyederhanakan persoalan atau bahkan menyesatkan. Dalam konteks pendidikan, diperlukan pergeseran paradigma di dunia pendidikan Islam ke arah pendidikan humanistik multikultural.

\section{B. Pengertian Pendidikan Humanistik-Multikultural}

\section{Pendidikan Humanistik}

Pendidikan humanistik merupakan proses pembangunan karakter kemanusiaan dalam diri manusia, yang menghargai harkat dan martabat manusia sebagai makhluk yang paling sempurna, makhluk multidimensi. ${ }^{2}$ Manusia memiliki berbagai potensi yang bersifat integralistik yang tidak dimiliki oleh makhluk lainnya, meliputi potensi fisik, intelektual, spiritual, moral, dan sosial. Melalui kelima ruang lingkup potensial tersebut, manusia dapat menjalani dan mengembangkan hidupnya dengan baik guna memeroleh tujuan hidupnya yang tertinggi mewujudkan hidup yang berkualitas secara lahir dan batin, individual maupun sosial. Pendidikan humanistik berupaya mengembangkan potensi jasmani, mensucikan ruhani, dan mencerdaskan akal secara interkonektif-integralistik. Pendidikan humanistik, dengan demikian, merupakan suatu proses pembudayaan manusia melalui pendidikan yang manusiawi.

Dalam hal ini, pendidikan, setidaknya, berorientasi pada dua level, yaitu: level individu dan level kelompok. Level individu bertujuan melahirkan pribadi yang cerdas akalnya, sehat dan kuat jasmaninya, serta suci dan tulus ruhaninya. Eksistensi dirinya

2 Zamroni, "Tajdid Pendidikan dalam Era Globalisasi: Memanusiakan Manusia untuk Pencerahan Peradaban," dalam Mifedwill Jandra dan M. Safar Nasir, Tajdid Muhammadiyah untuk Pencerahan Peradaban, (Yogyakarta: UAD Press, 2005), h. 151. 
tidak hanya bermanfaat bagi dirinya sendiri tetapi juga bagi orang lain. Selanjutnya, pada level kelompok, pendidikan humanistik dapat melahirkan masyarakat terbaik, yaitu masyarakat kelompok yang mampu mentransformasikan nilai-nilai ketuhanan dan kemanusiaan dalam tataran historisitas bagi kemajuan dan kemaslahatan umat manusia beserta lingkungan hidupnya. Ringkasnya, pendidikan humanistik bertujuan untuk membangun manusia sebagai pribadi yang utuh dan membangun kelompok masyarakat yang kokoh dan kuat.

Pendidikan humanistik, tampaknya, identik dengan pendidikan yang bermakna. ${ }^{3}$ Yaitu, suatu sistem pendidikan yang menekankan pengembangan watak atau karakter/moral dalam sistem nilai dan aktualisasi diri peserta didik. Pendidikan yang bermakna mengedepankan pendidikan sebagai proses interaksi manusia secara organik. Sistem organik berpandangan bahwa produk suatu proses pendidikan tergantung pada bagaimana interaksi antara berbagai faktor dalam proses pembelajaran. Interaksi yang positif akan menghasilkan energi positif dan menghasilkan produk yang berkualitas. Sebaliknya, interaksi negatif akan melahirkan energi negatif dan akan menghasilkan produk yang tidak berkualitas. Dengan demikian, pendidikan merupakan sekumpulan interaksi yang terjadi dari berbagai unsur dalam pendidikan. Kualitas interaksi akan menentukan kualitas proses yang pada gilirannya akan menentukan kualitas hasil pendidikan.

Pendidikan humanistik berbeda dengan sistem pendidikan yang menekankan pemupukan pengetahuan (knowledge deposit). Sistem pendidikan yang menekankan knowledge deposit memandang pendidikan sebagai suatu sistem mekanik. Sistem

\footnotetext{
3 Zamroni, ibid.,
} 
mekanik memperlakukan pendidikan sebagai suatu proses produksi dengan didasarkan pada pendekatan fungsi produksi yang berprinsip bahwa produk dari suatu proses produksi ditentukan secara langsung dan linier oleh faktor-faktor produksi.

\section{Pendidikan Multikultural}

Pendidikan multikultural ${ }^{4}$ merupakan corak pendidikan yang menekankan pendekatan progressif untuk memungkinkan semua siswa memperoleh pendidikan yang adil dan berkualitas sesuai dengan berbagai latar belakang budayanya. Pendidikan multikultural menggunakan pendekatan yang positif dan toleran terhadap koeksistensi dari serangkaian nilai dan praktik kultural yang berbeda-beda pada masyarakat. Sikap positif dan toleransi terhadap keberagaman kelompok kultural ditunjukkan dalam bentuk kebijakan pendidikan. Ringkasnya, pendidikan multikultural bertujuan mengakomodasi perbedaan-perbedaan, memberikan dan menjamin kesamaan hak atau kedaulatan di antara kelompok-kelompok kultural dalam proses pendidikan. 5

Berdasarkan pengertian di atas, dapat dirumuskan bahwa pendidikan humanistik multikultural merupakan model atau proses pendidikan yang bertujuan memanusiakan manusia menjadi manusia seutuhnya yang memiliki kesadaran bahwa perbedaan-perbedaan yang ada dalam kehidupan umat manusia tidak seharusnya menghilangkan nilai dan praktik kultural dari

${ }^{4}$ Konsep pendidikan multikultural muncul di Amerika Serikat pada 1970-an sebagai reaksi atas kegagalan kebijakan "melting pot"---suatu kebijakan yang bertujuan untuk menyatukan budaya minoritas dari berbagai kelompok masyarakat, khususnya masyarakat berkulit hitam ke dalam budaya mayoritas (kulit putih) kelompok Kristen Anglo-Saxon, sehingga kelompok minoritas dapat berkembang sebagaimana kelompok kulit putih---dalam menciptakan kesatuan dalam sistem sosial-budaya masyarakat. Melani Budianta, "Multiculturalism: in Search of a Critical Framework for Assesing Diversity in Indonesia", h. 24-25, dalam Kamanto Sunarto dkk (ed.), Multiculturalism Education in Indonesia and Southeast Asia, Jurnal Antropologi Indonesia (Depok: UI, 2004).

${ }^{5}$ Bandingkan, Rida Ahida, Keadilan Multikultural, (Ciputat: P3M STAIN Bukit Tinggi dan Ciputat Press, 2008), h. 59. 
masing-masing kelompok dalam pergaulan. Pendidikan humanistik multikultural memandang bahwa perbedaan nila-nilai dan praktik-praktik kultural manusia tidak mesti dipandang sebagai faktor penyebab terjadinya konflik di antara mereka. Akan tetapi, melalui pendidikan humanistik multikultural diharapkan akan terlahir kesadaran dalam diri peserta didik untuk melindungi dan mempromosikan nilai-nilai kemanusiaan di satu sisi dengan melindungi perbedaan-perbedaan dari kelompok-kelompok kultural yang seharusnya hidup dan berinteraksi bersama secara fleksibel dan terbuka.

\section{Strategi Pendidikan Agama Islam Bercorak Humanistik- Multikultural}

Pendidikan Agama Islam bercorak humanistik-multikultural, setidaknya dapat mempertimbangkan empat strategi. Pertama, mahasiswa dan anak didik perlu diperkenalkan persoalanpersoalan modernitas serta perkembangan pendekatan keilmuan sosial keagamaan yang berkembang di era kontemporer, di samping uraian tentang ilmu-ilmu keislaman klasik. Kedua, pengajaran ilmu-ilmu keislaman tidak indentik dengan indoktrinasi, akan tetapi sebagai upaya objektif menguraikan dimensi historis dari doktrin-doktrin tersebut. Praktik-praktik pendidikan Islam dituntut untuk menonjolkan nilai-nilai Alqur'an yang besifat universal-transendental-transkultural. Hal itu penting agar umat Islam tidak kehilangan makna keagamaan yang mendasar, sehingga mereka dapat menyaring berbagai nilai budaya asing dan lokal yang bersifat merusak. Sebab, jika umat kehilangan makna keagamaan berarti mereka kehilangan relevansi yang selalu dituntut pada setiap zaman untuk mengaktualisasikan dan mengkontekstualisasikan ajaran-ajaran agama. Nilai-nilai 
fundemantal ajaran Alqur'an dipraktikkan dalam semangat humanis kekehalifahan, sementara tindakan, amalan-amalan keagamaan dan aktivitas kelembagaan Islam harus disertai pertimbangan dan semangat nilai-nilai Alqur'an. Atas dasar itu, menjadi sangat dimungkinkan munculnya telaah kritis apresiatifkonstruktif terhadap khazanah intelektual Islam klasik. Sikap seperti itu akan memberi peluang dan kesempatan pelatihan bagi peserta didik untuk merumuskan ulang pokok-pokok doktrin agama sesuai tantangan dan tuntutan zaman, serta upaya mencari solusi yang sesuai dengan nilai-nilai keagamaan yang mereka yakini. Jadi, kontekstualisasi nilai-nilai ajaran agama tidak hanya menjadi filter terhadap berbagai nilai-nilai budaya yang berasal dari berbagai penjuru dunia, akan tetapi juga sebagai alat pengembang model-model pendidikan yang telah ada. Ringkasnya, tugas pokok pendidikan Islam adalah mengubah dan membentuk sikap serta perilaku anak didik dan warga masyarakat secara keseluruhan menurut nilai-nilai Alqur'an.

Ketiga, pengajaran yang hanya bertumpu pada teks, sebagaimana yang ditradisikan dalam pembelajaran filsafat pendidikan Islam pada masa lalu, misalnya, perlu diimbangi dengan telaah terhadap konteks dan realitas kehidupan masyarakat secara kritis dan mendalam. Hal ini penting, sebab teks (nash) sifatnya terbatas, sedangkan kejadian dan peristiwa yang dihadapi oleh umat manusia selalu berkembang. Oleh karena itu, diperlukan ilmu-ilmu bantu untuk menjelaskan hakikat, visi, dan misi agama Islam yang fundamental. Pendidikan Islam memiliki kaitan erat dengan dimensi praksis-sosial keagamaan untuk tidak mengatakannya terbatas pada kajian pemikiran teoritik-konseptual. Atas dasar itu, pendidikan Islam yang terkait langsung dengan isu-isu dan rekayasa sosial-budaya (socio-cultural 
engineering) suatu bangsa dapat saja dipahami melalui pendekatan hermenetika. ${ }^{6}$ Selama ini pemikiran pendidikan Islam, khususnya, lebih terkait dengan pendekatan teoritis-konseptual, sedangkan manifestasi dan keterlibatannya dalam kehidupan sosial melalui pendekatan sosial-budaya kurang mendapat perhatian secara serius. Dalam hemat M. Amin Abdullah, 7 corak pemahaman keagamaan Islam yang bersifat hermenetik inilah yang cocok dan perlu dijadikan sebagai paradigm basis epistemologis pendidikan Islam di tanah ain mengingat situasi praksis sosial di Indonesia berbeda dari wilayah lain. Pendekatan hermenetika ini mengandaikan adanya bentuk hubungan dialogis, dialektis, dan kritis antara aspek normativitas nilai-nilai Alqur'an (sifatnya universal, transendental, dan transkultural) dengan aspek historisitas pelaksanaan dan penerapannya dalam wilayah praksis sosial yang bersifat partikular, kultural, sosiologis keindonesiaan. Jika pada wilayah praksis pendidikan Islam terjadi hal-hal yang kontradiktif, nilai-nilai Alqur'an yang bersifat universal-transendental tersebut dapat kembali berperan mengoreksi, mengkritik, dan menafsirkan ulang bagaimana seharusnya praktik-praktik pendidikan Islam pada level historis itu agar segera dibenahi dan diperbaiki. Dengan demikian, living dan current issues yang secara langsung maupun tidak langsung terkait dengan pendidikan Islam menjadi agenda penting dalam rangka melakukan rekonstruksi pola dan sistem metodologi praktik pendidikan Islam di tanah air. Metodologi pendidikan Islam di Indonesia, hemat M. Amin Abdullah, perlu mencerminkan

${ }^{6}$ Metode hemeneutika, suatu metode keilmuan untuk memahami dan sekaligus menafsirkan fenomana-fenomena social, keagamaan, dan kebudayaan. E. Sumaryono, Hermeneutika: Sebuah Metode Filsafat, (Yogyakarta: Kanisius, 1993), h. 23-33. Van Peursen, Susunan Ilmu Pengetahuan: Sebuah Pengantar Ilmu, terjemahan J. Dros, (Jakarta: PT Gramedia, 1989), h. 155.

${ }^{7}$ M. Amin Abdullah, "Epistemologi Pendidikan Islam Era Pluralitas Agama dan Budaya", dalam op.cit., h. 62-63. 
pola hubungan dan pemahaman yang bersifat dialogis-dialektishermenetik, sehingga tidak terlalu tampak warna rigiditas tekstual-skriptualnya.

Keempat, era pluralitas iman semakin mencuat dan menguat. Menghadapi kenyataan ini diperlukan telaah akademik filosofis terhadap khazanah intelektual Islam klasik, khususnya tasawuf untuk mengimbangi telaah doktrinal ilmu kalam. Materi dan metodologi pendidikan agama harus mampu dikembangkan sejalan dengan isu-isu yang sedang berkembang sesuai dengan tuntutan perkembangan kehidupan sosial-keagamaan di luar bangku sekolah dan kuliah. Materi buku-buku dasar agama harus dibiasakan menyentuh isu pluralitas agama.

Oleh karena itu, materi pluralitas agama dan kemajemukan keberagamaan tidak semata-mata diperoleh anak didik lewat Pendidikan Kewarganegaraan (civic education) dan Pendidikan Moral Pancasila, akan tetapi masuk dalam satu komponen utuh materi pendidikan agama. Jadi, reformasi dalam bidang pendidikan agama lebih ditekankan daripada aspek konservasi dan pemeliharaan materi serta silabus pendidikan yang sudah tersedia sebagaimana tersistematisasi dalam silabus dan kurikulum dalam dunia rutinitas kegiatan pembelajaran seharihari. Selanjutnya, penekanan aspek kognitif terhadap anak didik perlu diimbangi dengan aspek afektif dan psikomotorik yang lebih menekankan pada kematangan dan kedewasaan berpikir dan berperilaku, seperti: penanaman sifat rendah hati, kesabaran, toleransi, tenggang rasa, kepuasan batin, cara berpikir yang matang, dan lain-lain.

Dengan demikian, pendidikan multikultural sangat berbeda dengan model pendidikan dan pengajaran agama di era klasik skolastik yang sifatnya terlalu menekankan aspek doktrin 
keselamatan individu melalui perbuatan kebaikan seseorang dengan Tuhannya. Akan tetapi, kurang memberikan tekanan yang baik antara diri individu dengan individu-individu sesamanya. Artinya, dalam hal ini pendidikan agama hanya semata-mata menekankan keselamatan individu dan kelompoknya sendiri. Keselamatan individual dipandang jauh lebih pokok dan lebih utama daripada keselamatan sosial. Akibatnya, anak didik menjadi kurang begitu sensitif atau kurang peka terhadap nasib, penderitaan, dan kesulitan yang dihadapi oleh sesama manusia yang berbeda agama. Sedangkan pendidikan multikultural berorientasi pada upaya penanaman kepada anak didik sikap empati, simpati, solidaritas, keadilan, dan toleransi terhadap sesama yang tidak seagama. Pendidikan multikultural lebih menekankan proses edukasi sosial dan tidak lagi semata-mata individual. Isu-isu transparansi, akuntan publik, pertanggungjawaban, debat publik, kesalehan sosial, pluralisme, dan kontrak sosial menjadi bahan-bahan atau materi kajian yang harus dikembangkan. Hal ini penting dikemukakan oleh karena semua individu dan kelompok sosial diasumsikan mempunyai flatform, hal dan kewajiban yang sama, sekalipun mereka berbeda ras, suku, golongan, agama, dan kepercayaan.

Skema Strategi Pendidikan Humanistik-Multikultural 


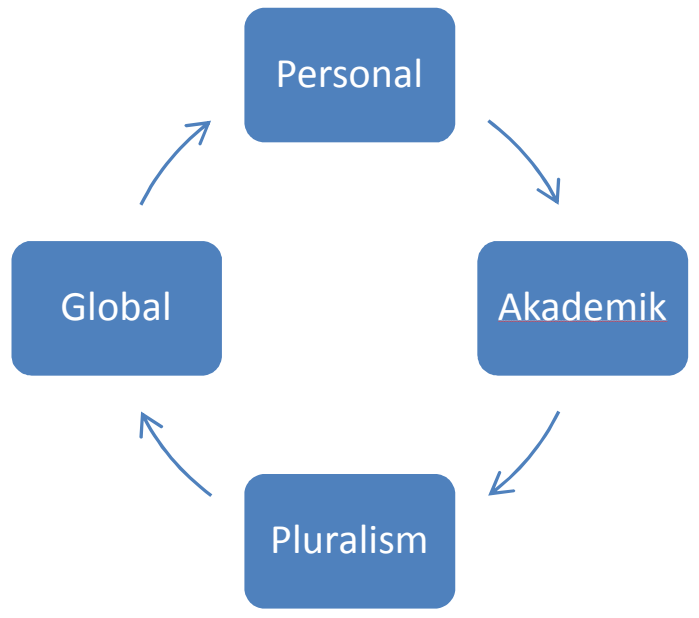

\section{Reorientasi Tujuan Pendidikan Agama Islam Model Humanistik-Multikultural}

Dalam berbagai buku teks standar yang dipelajari di IAIN dan dijadikan rujukan utama pengelola dan guru, ditegaskan bahwa tujuan pendidikan Islam atau pendidikan agama Islam ialah membentuk kepribadian Muslim berakhlak mulia. Pembelajaran setiap bidang studi keislaman juga untuk mencapai tujuan makro tersebut. Dalam penyelenggaraannya, pencapaian tujuan, penyusunan kurikulum, metode, dan strategi pembelajaran agama Islam itu cenderung bersudut pandang eksklusivisme.

Sementara paradigma pendidikan agama Islam model humanistik multikulturalisme mengharuskan perubahan tujuan pendidikan agama Islam, baik pada level makro maupun mikro ${ }^{8}$ dengan tetap menghubungkannya dengan perilaku sosial peserta didik. Dalam konteks pluralisme keagamaan misalnya, tujuan

8 Bandingkan, Abdul Munir Mulkhan, "Pendidikan Islam Multikultural", dalam Kesalehan Multikultural, (Jakarta: PSAP, 2005), h. 182. 
pendidikan tauhid perlu disusun dalam rumusan kultural bukan doktrinal atau struktural. Jika semula tujuan pendidikan tauhid bersifat spesifik dan eksklusif, yaitu membentuk keyakinan peserta didik secara indoktrinatif tentang Tuhan Yang Maha Esa dan satu-satunya ajaran agama yang benar adalah Islam, maka tujuan pendidikan tauhid dalam paradigma humanistik multikultural lebih kepada upaya menumbuhkan kesadaran dan komitmen atas ketuhanan. Jadi, pembelajaran di bidang teologis ini diubah menjadi pengkayaan pengalaman berketuhanan dan pengalaman mengalahkan tradisi setan dan kekafiran, bukan sebagai isolasi peserta didik dari segala persoalan kekafiran dan tradisi setan. Artinya, pendidikan agama Islam dilakukan secara inklusif dan lebih menekankan aspek edukatif (tarbiyah) bukan dakwah.

Dengan demikian, rumusan tujuan pendidikan agama Islam dan pendidikan tauhid lebih berdimensi substantif. Atas dasar itu, diperoleh suatu rumusan bahwa Tuhan dan ajaran atau kebenaran yang satu yang diyakini pemeluk Islam itu bersifat universal. Konsekuensinya, Tuhan pemeluk agama lain, sebenarnya ialah Allah sebagaimana yang dimaksud dan diyakini pemeluk Islam. Sebab, Tuhan hanyalah satu (esa). Kebenaran ajaran Tuhan yang diyakini pemeluk agama lain itu, dengan demikian, sebenarnya merupakan kebenaran yang diyakini oleh pemeluk Islam. Persoalannya kemudian adalah beranikah dan bersediakan para pelenyenggara pendidikan dalam artian yang seluas-luasnya mengubah rumusan keyakinan, rumusan tentang Tuhan, dan ajaran-ajarannya.

Terlepas dari persoalan tersebut, hal penting yang perlu diperhatikan sebagai tujuan pendidikan agama Islam bercorak humanistik-multikultural itu dapat diperikan sebagai berikut. 
Pertama, peserta didik dapat mengembangkan potensi dirinya sebagai insan beragama (homo religious) secara optimal. Kedua, peserta didik dapat mengembangkan pemikiran keagamaan secara kritis dan konstruktif. Ketiga, peserta didik dapat berpartisipasi secara aktif dalam proses belajar mengajar sesuai dengan faham keagamaannya masing-masing. Keempat, peserta didik dapat bersikap positif terhadap individu dan kelompok yang berbeda agama dan keyakinan dengan dirinya. Kelima, peserta didik dapat menjadi warga negara yang baik dan menjadi warga masyarakat yang partisipatif. Keenam, peserta didik dapat mengambil keputusan secara rasional dalam kehidupan sehari-hari. Ketujuh, peserta didik dapat mengevaluasi pengetahuan dari berbagai perspektif. Ringkasnya, pendidikan humanistik multikultural bertujuan untuk menciptakan Sumber Daya Manusia (SDM) yang terampil, intelek, etis, dan empatik secara individual maupun sosial guna melahirkan masyarakat sejahtera (welfare society), yaitu masyarakat yang terpenuhi kebutuhan lahir dan batinnya secara ekuilibrium, meliputi: kebutuhan pokok/primer (daruriyyah), kebutuhan sekunder (hajiyyah), dan kebutuhan pelengkap (tahsiniyyah) menyangkut dengan pemenuhan keimanan (agama), pengamanan jiwa, pencerdasan akal, mengatur keturunan, dan memelihara harta kekayaan guna kemaslahatan hidup manusia.

\section{E. Urgensi dan Relevansi Pendidikan Agama Islam Model Humanistik-Multikultural Terhadap Pembinaan Generasi Muslim Indonesia}

Manusia di zaman modern cenderung menjalani hidupnya secara ironis paradoksal. Setelah berhasil menciptakan kemajuan peradaban modern, pada saat yang sama mereka menjadi pelayan 
bagi ciptaannya sendiri, berupa uang, ilmu, teknologi, dan bendabenda lainnya yang dianggap dapat menjadikan hidupnya bahagia. Manusia zaman modern, sebagaimana yang menjadi fenomena dalam masyarakat Barat, telah dirusak oleh ilmu pengetahuan dan teknologi sehingga masuk ke dalam jurang kehidupan yang munafik, congkak, dan korup. Kodrat manusia yang pada dasarnya baik (ahsan taqwîm), di zaman modern, dirusak oleh uang, ilmu pengetahuan, teknologi, peradaban, dan pergaulan yang palsu. 9

Dalam pada itu, pergaulan antarumat manusia, bangsa, etnis, agama, ras, suku, dan budaya di era globalisasi semakin hari semakin gencar, dekat, dan padat, sehingga tidak ada jarang ruang dan waktu yang berarti. Fenomena ini jika ditinjau dari sisi positif dapat meningkatkan komunikasi, pertukaran budaya, dan kerja sama antarumat manusia dalam skala luas guna meningkatkan taraf hidup umat manusia dalam artian yang seluas-luasnya secara mondial.

Namun, bila diperhatikan dari sisi negatif, perbedaan etnis, suku, budaya, dan agama tidak jarang dijadikan sebagai pemicu terjadinya konflik dan anarkhisme di kalangan masyarakat modern. Keberagaman dipandang menjadi sumber konflik dan perpecahan serta dasar legitimasi bagi munculnya klaim civilized dan uncivilized community, negara maju-negara terbelakang, Utara-Selatan, Timur-Barat, dan terjadinya hegemoni mayoritastirani minoritas dan seterusnya.

Berbagai persoalan zaman modern dan era globalisasi di atas, di satu sisi, tidak terlepas dari hilangnya jati diri manusia

\footnotetext{
${ }^{9}$ Sebagaimana dikutip dalam Darsono Prawironegoro, Filsafat Ilmu, (Jakarta: Nusantara Consulting, 2010), h. 184
} 
sebagai makhluk multidimensi. Manusia modern cenderung mengurung dirinya dalam penjara materialistik, sementara dimensi ruhaniahnya, sebagai penentu nilai-nilai kemanusiaanya dikebiri. Akibatnya, kepribadian manusia menjadi terpecah (spilit personality), sehingga manusia modern tidak utuh dalam mempertahankan dan meningkatkan taraf eksistensinya. Di sisi lain, ketidakharmonisan dan konflik yang sering terjadi di kalangan masyarakat yang majemuk lebih disebabkan tidak tertanamnya sejak dini semangat inklusif dalam kehidupan masyarakat antaretnis, ras, suku, dan agama.

Oleh karena itu, sebagai salah satu langkah untuk mengatasi berbagai persoalan kemanusiaan di zaman modern, sangat perlu diperbaharui sarana dan prasarana pendidikan 10 dalam artian seluas-luasnya, khususnya dalam kaitannya dengan kehidupan sosio-kultur keberagamaan. Mengingat, sebagaimana juga dinyatakan oleh UNESCO, paradigma pendidikan yang sedang berjalan di seluruh dunia tidak lagi cukup jika hanya bertahan pada aspek pengembangan kognitif (to know), pemberian bekal keterampilan (to do), dan bahkan tidak lagi cukup kalau hanya berujung pada usaha untuk memperbaiki moralitas dan integritas pribadi sebagamana yang ditekankan oleh paradigma pendidikan humanistik. Paradigma ini sudah dianggap kuno dan tidak lagi dapat memenuhi tuntutan globalisasi yang jauh melampaui ketiga aspek pengembangan tersebut. Paradigma pendidikan bangsa-bangsa di dunia, terlebih-lebih di Indonesia yang multikultural, perlu ditambah dengan upaya mengedepankan nilai-nilai yang mendukung terwujudnya kehidupan yang damai

10 Sebagai langkah awal rekonstruksi metodologi pengajaran agama lihat M. Amin Abdullah, "Pengajaran Kalam dan Teologi dalam Era Kemajemukan di Indonesia: Sebuah Tinjauan Materi dan Metodologi”, dalam Th. Sumartana, dkk., Pluralisme, Konflik, dan Pendidikan Agama di Indonesia, (Yogyakarta: Interfidei, 2001), h. 241-256. 
antarumat manusia dengan berbagai latar belakangnya yang berbeda-beda (to live together) sebagaimana yang dicanangkan dalam paradigma pendidikan multikultural. Dalam hal yang disebutkan terakhir ini, tampaknya, perlu mengedepankan nilainilai moral yang baru dalam pendidikan yang bermuara kepada semangat dan etos kerja sama (co-operation) antarsuku, etnis, ras, kelompok, dan penganut berbagai agama tanpa syarat apa pun. Anak didik agar selalu dilatih mencari dan memahami "prinsipprinsip dasar" dan "prinsip-prinsip umum" yang bersifat universal dan dapat menyangga tata bangunan sosial yang sewaktu-waktu dapat digoyang oleh arus deras globalisasi. Selanjutnya, perlu dipupuk dan diperkuat semangat kesediaan untuk merengkuh orang atau kelompok lain ke dalam keluarga dan kelompok sendiri (inklusif). Kemudian daripada itu, anak didik dibantu menumbuhkan kemampuan untuk menyatukan berbagai watak dan perilaku teman-teman sejawat yang berbeda-beda dengan berbagai cara, namun tanpa meninggalkan rasa yang menyakitkan, tanpa melukai perasaan, dan tanpa meninggalkan kekecewaan di antara sesama mereka. Di sinilah letak pentingnya kemampuan memahami watak seseorang dan karakteristik kelompok dengan berbagai bentuk pendekatan (ambiguous).

\section{F. Kesimpulan}

Pendidikan Islam berpola humanistik-multikulturalism, pada hakikatnya, bertujuan untuk menciptakan manusia seutuhnya baik secara individual maupun sosial. Yaitu, model pendidikan yang bertujuan membudayakan manusia sebagai makhluk multidimensi yang kuat secara fisik, memiliki kecerdasan akal, spritual, dan sosial. Pendidikan humanistik multikultural sangat penting artinya bagi upaya melahirkan peserta didik yang 
aktif dalam berinteraksi baik secara personal, akademik, lintas iman/keyakinan, dan kehidupan global.

\section{Daftar Pustaka}

Abdullah, M. Amin. "Pendidikan Islam dan Tantangan Modernitas," dalam Pendidikan Agama Era Multikultural Multireligius.Jakarta: PSAP, 2005.

--------- Epistemologi Pendidikan Islam Era Pluralitas Agama dan Budaya", dalam Pendidikan Agama Era Multikultural Multireligius.Jakarta: PSAP, 2005, h. 47-66.

--------"Pengajaran Kalam dan Teologi dalam Era Kemajemukan di Indonesia: Sebuah Tinjauan Materi dan Metodologi", dalam Th. Sumartana, dkk., Pluralisme, Konflik, dan Pendidikan Agama di Indonesia. Yogyakarta: Interfidei, 2001, h. 241256.

Ahida, Rida. Keadilan Multikultural. Ciputat: P3M STAIN Bukit Tinggi dan Ciputat Press, 2008.

Budianta, Melani. "Multiculturalism: in Search of a Critical Framework for Assesing Diversity in Indonesia", h. 24-25, dalam Kamanto Sunarto dkk (ed.), Multiculturalism Education in Indonesia and Southeast Asia, Jurnal Antropologi Indonesia. Depok: UI, 2004.

Mulkhan, Abdul Munir. "Pendidikan Islam Multikultural", dalam Kesalehan Multikultural. Jakarta: PSAP, 2005.

Peursen, Van. Susunan Ilmu Pengetahuan: Sebuah Pengantar Ilmu, terjemahan J. Dros. Jakarta: PT Gramedia, 1989.

Prawironegoro, Darsono. Filsafat Ilmu. Jakarta: Nusantara Consulting, 2010.

Sumaryono, E. Hermeneutika: Sebuah Metode Filsafat. Yogyakarta: Kanisius, 1993.

Zamroni, "Tajdid Pendidikan dalam Era Globalisasi: Memanusiakan Manusia untuk Pencerahan Peradaban," dalam Mifedwill Jandra dan M. Safar Nasir, Tajdid Muhammadiyah untuk Pencerahan Peradaban. Yogyakarta: UAD Press, 2005. 